Research.

\title{
THE INFLUENCE OF FINANCIAL LITERACY AND BEHAVIOR IN USING FINTECH PAYMENTS ON THE FINANCIAL MANAGEMENT OF JABODETABEK STUDENTS
}

\author{
Nuriza Nenden Irawan $^{1^{*}}$; Rindang Matoati ${ }^{2}$ \\ Department of Management, Faculty of Economics and Management, IPB University, Bogor, Indonesia \\ $\left.{ }^{*}\right)$ nenden_16@apps.ipb.ac.id; ${ }^{2)}$ rindang@apps.ipb.ac.id \\ ${ }^{*}$ Corresponding author
}

Received: September 10, 2021 Accepted: October 10, 2021 Published: December 30, 2021

To cite this article: Irawan, NN.; Matoati, R. (2021). The Influence of Financial Literacy and Behavior In Using Fintech Payments on The Financial Management of Jabodetabek Students. The Management Journal Of Binaniaga, 6 (2), 117-132 . doi:10.33062/mib.v6i2.459

\begin{abstract}
The low financial literacy of Indonesian students at $23.20 \%$ and the emergence of a technology called fintech payment which tends to change individuals encourages the creation of a cashless society. The younger generation has great potential in increasing the level of financial literacy and the ability to use financial services optimally which will have an impact on financial management. This research aims to 1) analyze the level of financial literacy, the level of behavior in using fintech payments, and the level of financial management in students in Jabodetabek, 2) analyze the effect of financial literacy on the financial management of students in Jabodetabek, and 3) analyze the effect of using fintech payments on financial management. students in Jabodetabek. The population of this research is Jabodetabek bachelor degree students. The sampling technique used is non-probability sampling with purposive sampling technique with 200 respondents. The method of analysis used descriptive analysis and PLS Structural Equation Modeling (SEM). The results showed that the average level of financial literacy for Jabodetabek students was $81.09 \%$ and classified as well literate, the behavioral level of using fintech payments was $84.43 \%$ and classified as very high, and the level of financial management for Jabodetabek students was $80.93 \%$ and classified as very good. Financial literacy and the behavior of using fintech payments partially have a positive and significant influence on financial management.
\end{abstract}

Keywords: Fintech payment, financial literacy, students, financial management

\section{INTRODUCTION}

\section{Background}

A person's ability to manage his finances is related to the ability to use financial concepts known as financial literacy. In the industrial era 4.0 with the rapid development of digital technology and indirectly triggering people's consumption behavior to use digital technology that makes it easy for everyone to shop and transact and can affect people's consumption patterns. With this phenomenon, it takes a person's financial intelligence in responding to this, especially in managing individual finances.

The Financial Services Authority (OJK) through the 2019 National Survey of Financial Literacy and Inclusion (SNLIK) found that Indonesia's financial literacy index in 2019 was $38.03 \%$. This percentage indicates that approximately 39 out of 100 people in Indonesia belong to the well literate category. This shows that the financial literacy index in Indonesia is quite low and needs to be improved. Indonesia's financial literacy index can be presented in Figure 1.

Nuriza Nenden Irawan; Rindang Matoati. The Influence Of Financial Literacy And Behavior In Using Fintech Payments On The Financial Management Of Jabodetabek Students 


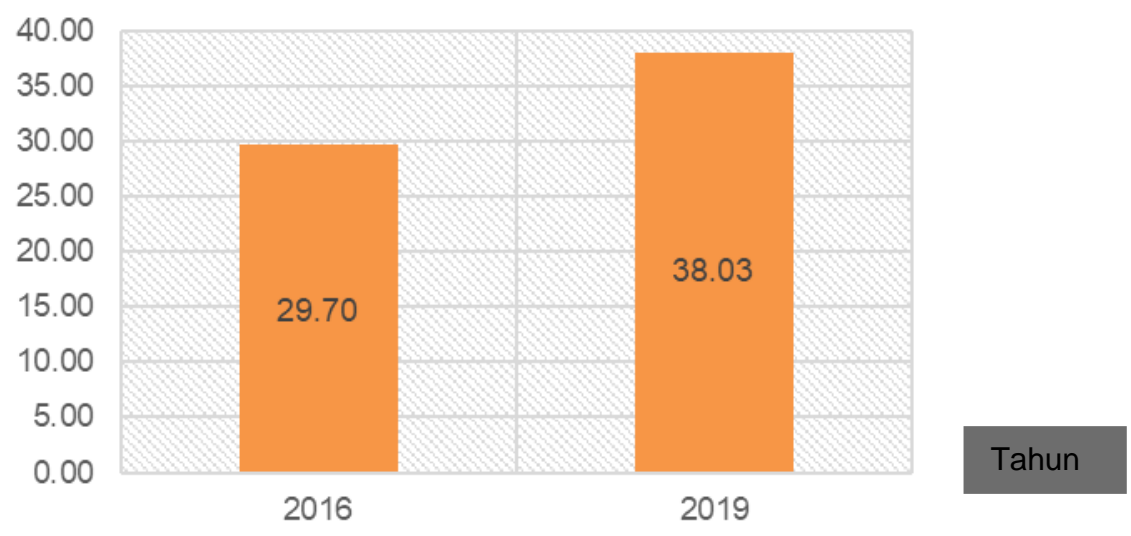

Figure 1 Indonesian Financial Literacy Index

Source: Financial Services Authority (2019)

In 2016, OJK launched a program called the National Strategy for Indonesian Financial Literacy (SNLKI) with the aim of increasing the financial literacy of the Indonesian people and being able to take advantage of appropriate financial products and services to create financial prosperity. One of the main focuses of the program is students. However, students in Indonesia have a low level of financial literacy (Margaretha and Pambudhi 2015). This is supported by the results of the 2016 National Survey of Financial Literacy and Inclusion (SNLIK) conducteded by the OJK, namely the level of financial literacy in students is only $23.20 \%$, which is still below the national average of the Indonesian financial literacy index of $29,70 \%$.

In addition to financial literacy which can affect one's financial management, along with the rapid advancement of information technology and the penetration of internet use in Indonesia which has an impact on innovation in the financial services industry, namely the emergence of digital financial services called financial technology (fintech). Technological advances in fintech payments are able to moderate one's financial management so that it can influence consumer decisions (See-To and Ngai 2018). This is in line with research conducteded by Yeo and Fisher (2017) which suggests that the more often a person uses fintech payments, the significantly higher the level of financial management and can make financial decisions.
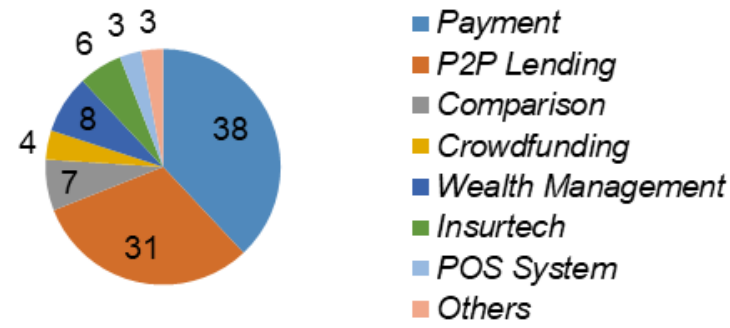

Figure 2 Distribution of Fintech in Indonesia in 2018 (\%) Source: Fintech Singapore (2018)

According to Figure 2, the most widely used fintech players in Indonesia are fintech payment-based services (fintech payment) at $38 \%$. Fintech payment is a combination of financial services and technology that plays an important role in Digital Payments, both in Digital Commerce for online shopping transactions or on Mobile POS Payments to make offline payments using digital payment technology (Statista 2020). In fintech payments, the most widely used services include e-wallet and payment gateways. The number of players using fintech payments has encouraged the creation of a cashless society in Indonesia. The use of fintech payments with ease now makes its development more rapid and also has the potential to affect a person's behavior in managing his finances.

Nuriza Nenden Irawan; Rindang Matoati. The Influence Of Financial Literacy And Behavior In Using Fintech Payments On The Financial Management Of Jabodetabek Students 
The development of fintech is supported by the number of internet users in Indonesia which continues to increase. In 2019, internet user penetration in Indonesia reached 196.71 million people (73.70\% of the population in Indonesia) (APJII 2020). According to the results of the Indonesian Population Census (2020), the population in Indonesia is dominated by Generation Z, amounting to $27.94 \%$ of the total population of Indonesia. Generation Z is a generation born in 1995-2010 with an estimated age in 2021 , which is between 11-26 years and is famous for the generation that is familiar with technology. One part of Generation Z is the students. This means that students have the potential to be the community group most affected by the existence of fintech. On the other hand, Java Island is the island with the largest internet users in Indonesia with a percentage of $56.40 \%$ and Jabodetabek is one of the areas with the most internet users. In addition, Jabodetabek is also a more developed area compared to other areas and is a metropolitan city that is the center of the economy. This is the reason the author chose Jabodetabek students.

Students have great potential in increasing their level of financial knowledge and ability to use financial services optimally (OJK 2019). The level of financial literacy among university students tends to influence their financial behavior (Chen and Volpe 1998). Students as generation $Z$ are very familiar with the use of technology where this generation wants everything practically and easily with one example using technology called fintech payment so that it tends to affect their financial management related to planning, controlling, managing, financial irregularities, and decisions in finance. Erlangga and Krisnawati (2020); Ali et al.

\section{Formulation of the Problem}

1. What is the level of financial literacy, the level of behavior in using fintech payments, and the level of financial management for students in Jabodetabek?

2. How does financial literacy affect student financial management in Jabodetabek?

3. How does the use of fintech payments affect student financial management in Jabodetabek?

\section{LITERATURE REVIEW}

\section{Financial Literacy}

Financial literacy is knowledge, skills, and beliefs that influence attitudes and behavior to improve the quality of decision making and financial management in order to achieve prosperity (Financial Services Authority 2016). In addition, OJK (2013) divides the level of financial literacy in Indonesia into four categories, namely well literate, sufficient literate, less literate, and not literate.

\section{Financial Management}

Financial management is the goal-oriented acquisition, allocation, and use of financial resources (Horne and Wachowicz 2005). According to Cummins et al. (2009), the capability of an individual in managing his finances is an influential factor in achieving prosperity, therefore the need for knowledge in managing finances is appropriate for each individual.

\section{Financial Technology}

According to Bank Indonesia (2017) in Bank Indonesia Regulation Number 19/12/PBI/2017 Article 1 paragraph 1 concerning the Implementation of Financial Technology explains that financial technology is the use of technology in the financial system that produces products, services, technology, and/or or new business models and may have an impact on monetary stability, stability, financial system, and/or efficiency, smoothness, security, and reliability of payment systems. Bank Indonesia (2017) classifies the types of fintech into four categories, including Crowdfunding and Peer to

Nuriza Nenden Irawan; Rindang Matoati. The Influence Of Financial Literacy And Behavior In Using Fintech Payments On The Financial Management Of Jabodetabek Students 
Peer (P2P) Lending, Market Aggregator, Risk and Investment Management, and Payment, Settlement, and Clearing.

\section{Fintech Payment Behavior}

The use of fintech payments can be one of the technologies that can measure the level of acceptance. There are five behavioral dimensions of using fintech payments according to Junadi and Sfenrianto (2017):

1. Effort Expectancy

The comfort felt by a fintech payment user as measured by ease of use, flexibility and transactions.

2. Performance Expectancy

Someone's opinion about the use of fintech payments that will provide benefits in transactions measured in terms of productivity, convenience, and speed of transactions.

3. Social Influence

The influence of the closest people who encourage someone to use fintech payments, is measured by how the closest people use fintech payments and recommend and support someone to use it as well.

4. Perceived Security

How safe are users' feelings when using fintech payments in transactions, in this case related to technical protection from providers, security statements from applications, as well as rules and regulations from the government and central bank.

5. Culture

Cultural factors as measured by internet access, smartphone use, and education level that influence users to use fintech payments.

\section{RESEARCH METHODS}

\section{Data Collection Technique}

The data used are primary data and secondary data. The primary data used in this research is a questionnaire filled out by respondents online. While the secondary data in this research were obtained through literature studies from several journals, books, and mass media articles related to the topic of this research. This research questionnaire was adapted from the research of Chen and Volpe (1998), Kim et al. (2016), and Xiao (2011) and adapted to the object of research, namely students. The scale used in measuring the questionnaire is the Likert scale. The Likert scale in this research uses a scale of 1 to 4.

\section{Sampling Technique}

The sampling technique used in this research is non-probability sampling with purposive sampling technique. The criteria for respondents in this research are:

a. Students who are currently pursuing bachelor degree education (S1) at universities located in Greater Jakarta and domiciled in Greater Jakarta

b. 8-26 years old.

c. Students who use fintech payment services.

Determination of the sample size in this research using the formula Lemeshow (1990). The Lemeshow formula is a formula for determining the sample size of an unknown population. According to this formula, the minimum respondents needed in this research were 196 respondents. However, to reduce errors and to better represent the population, in this research the total sample was rounded to 200 respondents.

\section{Research Variables}

The variables in this research were classified into independent variables and dependent variables. The independent variable is financial literacy $(X 1)$ and the behavior of using fintech payment (X2) and the dependent variable is financial management $(\mathrm{Y})$. The definition of operational variables is as follows:

Nuriza Nenden Irawan; Rindang Matoati. The Influence Of Financial Literacy And Behavior In Using Fintech Payments On The Financial Management Of Jabodetabek Students 
The Management Journal of BINANIAGA Vol. 06, No.02, December 2021

Table 1 Definition of operational variables

\begin{tabular}{|c|c|c|c|}
\hline Variables & Dimension & Definition & Source \\
\hline \multirow[t]{4}{*}{$\begin{array}{l}\text { Financial } \\
\text { Literacy }\end{array}$} & $\begin{array}{l}\text { General } \\
\text { knowledge about } \\
\text { finance }\end{array}$ & $\begin{array}{l}\text { General knowledge of finance According to } \\
\text { several things such as knowledge of interest } \\
\text { rates, inflation, and exchange rates } \\
\text { General knowledge of finance According to } \\
\text { several things such as knowledge of interest } \\
\text { rates, inflation, and exchange rates }\end{array}$ & \multirow[t]{4}{*}{$\begin{array}{l}\text { Chen and } \\
\text { Volpe (1998) }\end{array}$} \\
\hline & Savings and loans & $\begin{array}{l}\text { Individual knowledge of banking products } \\
\text { which include savings, time deposits, and } \\
\text { credit }\end{array}$ & \\
\hline & Investation & $\begin{array}{l}\text { Individual knowledge about the extent to } \\
\text { which a person knows the types of } \\
\text { investments and the risks faced when } \\
\text { choosing a particular type of investment }\end{array}$ & \\
\hline & Insurance & Individual knowledge of insurance products & \\
\hline \multirow[t]{3}{*}{$\begin{array}{l}\text { Fintech } \\
\text { Payment } \\
\text { Behavior }\end{array}$} & Effort Expectancy & $\begin{array}{l}\text { The comfort felt by a fintech payment user as } \\
\text { measured by ease of use, flexibility and } \\
\text { transactions }\end{array}$ & \multirow[t]{3}{*}{$\begin{array}{l}\text { Junadi and } \\
\text { Sfenrianto } \\
\quad(2017) ; \\
\text { Forbes and } \\
\text { Kara (2010) }\end{array}$} \\
\hline & $\begin{array}{l}\text { Performance } \\
\text { Expectancy }\end{array}$ & $\begin{array}{l}\text { Someone's opinion about the use of fintech } \\
\text { payments that will provide benefits in } \\
\text { transactions measured in terms of } \\
\text { productivity, convenience, and transaction } \\
\text { speed }\end{array}$ & \\
\hline & Social Influence & $\begin{array}{l}\text { The influence of the closest people who } \\
\text { encourage someone to use fintech } \\
\text { payments, is measured by how the closest } \\
\text { people use fintech payments and } \\
\text { recommend and support someone to use it } \\
\text { as well. }\end{array}$ & \\
\hline \multirow[t]{2}{*}{$\begin{array}{l}\text { Fintech } \\
\text { Payment } \\
\text { Behavior }\end{array}$} & $\begin{array}{l}\text { Perceived } \\
\text { Security }\end{array}$ & $\begin{array}{l}\text { How safe are users' feelings when using } \\
\text { fintech payments in transactions, in this case } \\
\text { related to technical protection from providers, } \\
\text { security statements from applications, as } \\
\text { well as rules and regulations from the } \\
\text { government and central bank. }\end{array}$ & \multirow[t]{2}{*}{$\begin{array}{l}\text { Junadi and } \\
\text { Sfenrianto } \\
\quad(2017) ; \\
\text { Forbes and } \\
\text { Kara (2010) }\end{array}$} \\
\hline & $\begin{array}{l}\text { Financial Self } \\
\text { Efficacy }\end{array}$ & $\begin{array}{l}\text { A person's trust or belief in his ability to } \\
\text { achieve financial goals by using fintech } \\
\text { payments. }\end{array}$ & \\
\hline \multirow[t]{3}{*}{$\begin{array}{l}\text { Financial } \\
\text { Management }\end{array}$} & Consumption & $\begin{array}{l}\text { One of the activities in using or spending } \\
\text { money by acting economically is considering } \\
\text { the results and sacrifices. }\end{array}$ & \multirow[t]{3}{*}{$\begin{array}{l}\text { Xiao and } \\
\text { Dew (2011), } \\
\text { and Senduk } \\
(2004)\end{array}$} \\
\hline & $\begin{array}{l}\text { Cash Flow } \\
\text { Management }\end{array}$ & $\begin{array}{l}\text { Cash flow management can be measured } \\
\text { from whether a person pays bills on time, } \\
\text { pays attention to financial records and } \\
\text { makes budgets and plans for the future. }\end{array}$ & \\
\hline & Risk Management & $\begin{array}{l}\text { Risk management is measured by whether } \\
\text { someone manages their risk by providing } \\
\text { funds for unexpected expenses (emergency } \\
\text { funds). }\end{array}$ & \\
\hline
\end{tabular}

Nuriza Nenden Irawan; Rindang Matoati. The Influence Of Financial Literacy And Behavior In Using Fintech Payments On The Financial Management Of Jabodetabek Students 


\begin{tabular}{ll}
\hline Financial Storage & $\begin{array}{l}\text { Activities in setting aside a certain amount of } \\
\text { income to be saved for special needs or } \\
\text { plans for the future. }\end{array}$
\end{tabular}

$\begin{array}{cc}\text { Financial } & \text { Activities in one's financial decisions. } \\ \text { Considerations }\end{array}$

\section{Data Processing and Analysis Method}

a. Descriptive Analysis

Descriptive analysis is an analysis used to analyze data by describing or portraying the data that has been collected as it is without intending to make conclusions that apply to the public or generalizations (Sugiyono 2016). Descriptive analysis in this research was used to obtain an overview of the level of financial literacy and behavior in using fintech payments, as well as financial management for Jabodetabek students. The analytical tool used is Microsoft Excel 2019.

b. Structural Equation Modeling-Partial Least Square (SEM-PLS) Analysis

SEM-PLS is a variant-based SEM statistical method designed to solve multiple regression when specific data problems occur, such as small research sample sizes, missing data values, and multicollinearity (Abdillah and Hartono 2015). The PLS SEM in this research was used to analyze the effect of financial literacy and the behavior of using fintech payments on the financial management of Jabodetabek students. The analytical tool used is SmartPLS 3.3.3.

\section{Research Hypothesis}

This research aims to identify the effect of financial literacy and the behavior of using fintech payments on financial management. Here are some hypotheses in this research:

1. According to Edrisinghe et al. (2017) that students' financial literacy has a direct effect on inancial management, so the following hypothesis is formulated:

$\mathrm{H}_{0.1}$ : Financial literacy has no positive and significant effect on financial management.

$\mathrm{H}_{1.1}$ : Financial literacy has a positive and significant effect on financial management.

2. Research by Erlangga and Krisnawati (2019) concludes that the use of fintech payments has a positive and significant effect on student financial management, so the hypothesis is formulated as follows:

$\mathrm{H}_{0.2}$ : The behavior of using fintech payments does not have a positive and significant effect on financial management.

$\mathrm{H}_{1.2}$ : The behavior of using fintech payments has a positive and significant effect on financial management.

\section{RESULTS AND DISCUSSION}

Respondents in this research were 200 bachelor degree students at Jabodetabek universities. The characteristics of the respondents in this research were grouped by category of gender, domicile, age, faculty origin, and monthly income/pocket money. Respondents of this research were dominated by female students, domiciled in Depok City with an age range of 20-21 years, and came from the faculties of economics, business, and management. The majority of respondents have an income/pocket money per month of $\operatorname{Rp} 1,000,000$.

\section{Jabodetabek Student Financial Literacy}

The categorization of student financial literacy levels in Jabodetabek refers to the categorization conducted by the Financial Services Authority (2013). The dimensions of

Nuriza Nenden Irawan; Rindang Matoati. The Influence Of Financial Literacy And Behavior In Using Fintech Payments On The Financial Management Of Jabodetabek Students 
financial literacy studied include the dimensions of general knowledge of finance, savings and loans, insurance, and investment. The categorization of the financial literacy level of students in Jabodetabek in this research is shown in Figure 3 below.

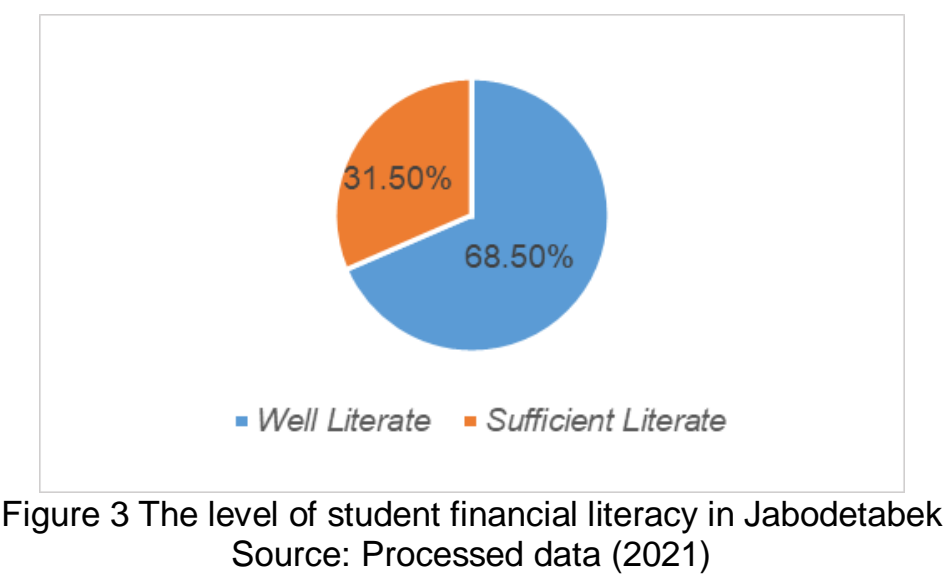

According to Figure 3, the level of financial literacy of Jabodetabek students is divided into two categories, namely well literate and sufficient literate. As many as $68.50 \%$ Jabodetabek students are included in the well literate category, which means that around 137 out of 200 Jabodetabek students have the knowledge, skills, and confidence in using products and services. This figure is higher than the financial literacy level According to the 2019 National Financial Literacy and Inclusion Survey, which is $38.03 \%$. Furthermore, as many as $31.50 \%$ of Jabodetabek students are included in the sufficient literate category or about 63 of 200 Jabodetabek students. A person is said to be sufficient literate if he has knowledge and confidence in the products and services of financial institutions. In this research, there are no respondents who are categorized into less literate and not literate categories.

The average level of financial literacy for Jabodetabek students is $81.09 \%$ or is in the well literate category. Being at the level of the well literate category means that on average Jabodetabek students have knowledge and confidence about financial service institutions and financial service products, including features, benefits and risks, rights and obligations related to financial products and services, and have skills in using products and services. finance. This is supported by data on the level of financial literacy from four dimensions which show that the level of knowledge and confidence of Jabodetabek students towards general knowledge of finance $(82.67 \%)$, the level of knowledge and confidence of Jabodetabek students to insurance $(82.08 \%)$, the level of knowledge and confidence Jabodetabek students to savings (83.87\%) and the level of knowledge and confidence of Jabodetabek students towards investment (77.92\%). According to these four dimensions, they are in the same range, which is included in the well literate category. The investment dimension is the lowest dimension with a value of $77.92 \%$, but is still included in the well literate category.

The high level of financial literacy belonging to the well literate category in this research was supported by the majority of Jabodetabek students from economic, business, and management faculties students $(52.50 \%)$. These results are reinforced by a research conducteded by Kusumawardhani et al. (2020) which shows that in the majority, bachelor degree students in economics, business, and management have higher financial literacy than bachelor degree students in non-economics, business, and management. In addition, bachelor degree students in economics, business, and management have better financial knowledge because they spend more time taking courses related to finance (Chen and Volpe 1998). The highest literacy value that can be obtained by respondents is $100.00 \%$ and the lowest literacy value is $62.50 \%$.

Nuriza Nenden Irawan; Rindang Matoati. The Influence Of Financial Literacy And Behavior In Using Fintech Payments On The Financial Management Of Jabodetabek Students 
The Management Journal of BINANIAGA Vol. 06, No.02, December 2021

p-ISSN: 2527 - 4317, e-ISSN: $2580-149 x$

$6^{\text {th }}$ Accreditation Rating: April 04, $2019-$ April 03, 2024

Table 2 The level of financial literacy of Jabodetabek students by dimension

\begin{tabular}{|c|c|c|c|c|}
\hline \multirow{2}{*}{$\begin{array}{c}\text { Dimensions of Financial } \\
\text { Literacy }\end{array}$} & \multicolumn{4}{|c|}{ Category } \\
\hline & $\begin{array}{l}\text { Not Literate } \\
(0 \%-20 \%)\end{array}$ & $\begin{array}{l}\text { Less Literate } \\
(26 \%-50 \%)\end{array}$ & $\begin{array}{c}\text { Sufficient Literate } \\
(51 \%-75 \%)\end{array}$ & $\begin{array}{l}\text { Well Literate } \\
(76 \%-100 \%)\end{array}$ \\
\hline General knowledge of finance & & & & 82.67 \\
\hline Savings and loans & & & & 82.08 \\
\hline Insurance & & & & 83.87 \\
\hline Investment & & & & 77.92 \\
\hline Average financial literacy & & & & 81.09 \\
\hline
\end{tabular}

Source: Processed data (2021)

\section{Behavior of Using Fintech Payment for Jabodetabek Students}

This research also examines the behavior of using fintech payments through questions According to the type of fintech payment used, number of Ownership, frequency, and volume and it is found that the most widely used fintech payment for Jabodetabek students is GoPay. The behavior of using fintech payments is dominated by the number of ownerships of 3-4 fintech payment accounts with a frequency of use 4-8 times a month with a transaction volume of IDR 100,001 - IDR 500,000 per month.

The behavioral category of using fintech payments in this research is divided into five categories, namely very low, low, medium, high, and very high. The level of behavior in using fintech payments is obtained from the average for each dimension. The average level of behavior in using fintech payments as a whole According to each dimension is $84.43 \%$ and is included in the very high category. This shows that fintech payments have grown rapidly among Jabodetabek students and the majority of students have adopted the technology as a transaction medium for their daily needs. The high behavior of using fintech payments among Jabodetabek students has encouraged the creation of a cashless society in Indonesia. On average, students think that fintech payments can help them in making payment transactions and managing their finances.

Table 3 The level of behavior in using fintech payments for Jabodetabek students

\begin{tabular}{lcc}
\hline \multicolumn{1}{c}{ Dimensi } & Persentase (\%) & Kategori \\
\hline Effort Expectancy & 94.47 & Very High \\
Performance Expectancy & 93.03 & Very High \\
Social Influence & 71.91 & High \\
Perceived Security & 77.44 & High \\
Self Efficacy & 85.29 & Very High \\
\hline \multicolumn{1}{c}{ Rata-rata } & 84.43 & Very High \\
\hline
\end{tabular}

Source: Processed data (2021)

According to Table 3, the highest percentage of the behavioral level of using fintech payment is on the effort expectancy dimension (94.47\%) and the lowest percentage is on the social influence dimension (71.91\%). The following is the average behavior for using fintech payments as a whole, which is depicted on a continuum.

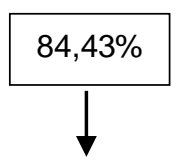

Nuriza Nenden Irawan; Rindang Matoati. The Influence Of Financial Literacy And Behavior In Using Fintech Payments On The Financial Management Of Jabodetabek Students 


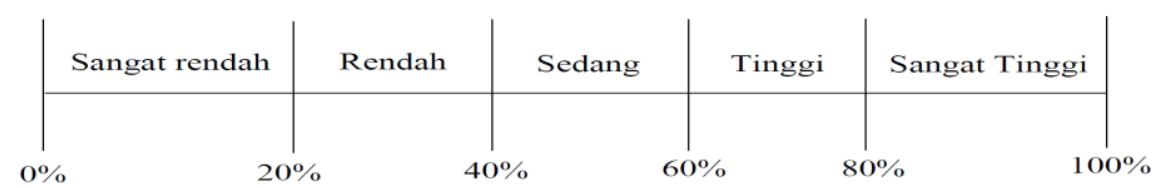

Figure 4 The continuum line of the overall level of fintech payment usage behaviorSource: Processed data (2021)

\section{Jabodetabek Student Financial Management}

The dimensions of student financial behavior in this research consisted of five dimensions, namely consumption, cash flow management, risk management, financial storage, and financial considerations. The category of student financial behavior in this research was divided into five categories, namely very bad, not good, not good, good, and very good. The level of student financial management is obtained from the average of each dimension.

The average level of financial management of Jabodetabek students as a whole is $80.93 \%$ and is included in the very good category. This shows that the majority of Jabodetabek students are able to manage their finances well which can be seen from the dimensions in each category in each dimension. The majority of students always make a financial plan and record all their financial income and expenses. In addition, they also evaluate expenses with financial planning that has been prepared. On average, students save regularly and have the courage to take risks in making their financial decisions and take responsibility for their financial decisions transaction payments and financial management.

Table 4 The level of behavior in using fintech payments for Jabodetabek students

\begin{tabular}{lcc}
\hline \multicolumn{1}{c}{ Dimension } & Percentage (\%) & Category \\
\hline Consumption & 84.31 & Excellent \\
Cash Flow Management & 74.18 & Good \\
Risk Management & 79.38 & Good \\
Financial Storage & 75.44 & Good \\
Financial Considerations & 91.33 & Excellent \\
\hline \multicolumn{1}{c}{ Average } & 80.93 & Excellent \\
\hline
\end{tabular}

Source: Processed data (2021)

According to Table 4, the highest percentage of financial management level is on the financial considerations dimension (91.33\%) and the lowest percentage is on the cash flow management dimension $(74.18 \%)$. The following is the overall average of financial management which is depicted in the continuum line in Figure 5.

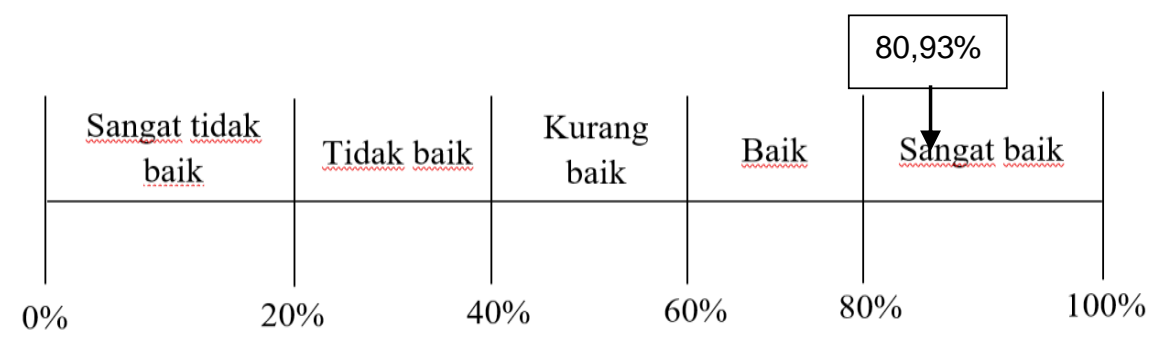

Figure 5 Continuum line of overall financial management level

Source: Processed data (2021)

\section{Structural Equation Modeling Analysis Partial Least Square (SEM PLS)}

Model testing on SEM is done by evaluating the measurement model (outer model) and structural model (inner model).

1. Evaluation of the Measurement Model (Outer Model)

Nuriza Nenden Irawan; Rindang Matoati. The Influence Of Financial Literacy And Behavior In Using Fintech Payments On The Financial Management Of Jabodetabek Students 
The evaluation of the outer model was conducted to test the validity and reliability of the constructs in describing the latent variables. There are three tests in this evaluation, namely convergent validity, discriminant validity, and composite reliability. Convergent validity test is seen According to the value of loading factor and Average Variance Extracted (AVE).

\section{Validity Test}

The indicator is considered valid as an indicator that can measure latent variables if it has a loading factor value above 0.70 but a loading factor value of 0.50 to 0.60 is still acceptable according to Chin (1998) in (Ghozali 2014). In this research, the standardized loading factor for each indicator is more than 0.50 . If the initial model contains an indicator with a loading factor value of less than 0.50 , then the indicator must be dropped (dropping) in order to obtain a valid convergent validity value as a whole.

Tabel 5 Nilai loading factor sebelum dan sesudah dropping

\begin{tabular}{lccc}
\hline Indicator & $\begin{array}{c}\text { Value of loading } \\
\text { factor before } \\
\text { dropping }\end{array}$ & Remarks & $\begin{array}{c}\text { Load factor value } \\
\text { after dropping }\end{array}$ \\
\hline Financial Literacy & & & Remarks \\
\hline LK1.1 & 0.144 & Not valid & Dropping done \\
LK1.2 & 0.398 & Not valid & Dropping done \\
LK1.3 & 0.548 & Valid & Dropping done \\
LK1.4 & 0.361 & Not valid & Dropping done \\
LK1.5 & 0.339 & Not k valid & Dropping done \\
LK1.6 & 0.584 & Valid & Dropping done \\
LK2.1 & 0.383 & Not valid & Dropping done \\
LK2.2 & 0.449 & Not valid & Dropping done \\
\hline
\end{tabular}

Table 5 Value of loading factor before and after dropping (continued)

\begin{tabular}{|c|c|c|c|c|}
\hline Indicator & $\begin{array}{l}\text { Value of loading } \\
\text { factor before } \\
\text { dropping }\end{array}$ & Remarks & $\begin{array}{l}\text { Load factor } \\
\text { value after } \\
\text { dropping }\end{array}$ & Remarks \\
\hline \multicolumn{5}{|c|}{ Financial Literacy } \\
\hline LK2.3 & 0.486 & Not valid & \multicolumn{2}{|c|}{ Dropping done } \\
\hline LK2.4 & 0.229 & Not valid & \multicolumn{2}{|c|}{ Dropping done } \\
\hline LK2.5 & 0.532 & Valid & \multicolumn{2}{|c|}{ Dropping done } \\
\hline LK2.6 & 0.397 & Not valid & \multicolumn{2}{|c|}{ Dropping done } \\
\hline LK2.7 & 0.289 & Not valid & \multicolumn{2}{|c|}{ Dropping done } \\
\hline LK3.1 & 0.624 & Valid & 0.666 & Valid \\
\hline LK3.2 & 0.594 & Valid & \multicolumn{2}{|c|}{ Dropping done } \\
\hline LK3.3 & 0.472 & Not valid & \multicolumn{2}{|c|}{ Dropping done } \\
\hline LK3.4 & 0.628 & Valid & 0.693 & Valid \\
\hline LK3.5 & 0.387 & Not valid & \multicolumn{2}{|c|}{ Dropping done } \\
\hline LK4.1 & 0.277 & Not valid & \multicolumn{2}{|c|}{ Dropping done } \\
\hline LK4.2 & 0.535 & Valid & \multicolumn{2}{|c|}{ Dropping done } \\
\hline LK4.3 & 0.639 & Valid & 0.726 & Valid \\
\hline LK4.4 & 0.301 & Not valid & \multicolumn{2}{|c|}{ Dropping done } \\
\hline LK4.5 & 0.584 & Valid & 0.766 & Valid \\
\hline LK4.6 & 0.302 & Not valid & \multicolumn{2}{|c|}{ Dropping done } \\
\hline \multicolumn{5}{|c|}{ Fintech Payment Behavior } \\
\hline FP1.1 & 0.645 & Valid & 0.668 & Valid \\
\hline FP1.2 & 0.653 & Valid & 0.768 & Valid \\
\hline FP1.3 & 0.622 & Valid & 0.787 & Valid \\
\hline FP1.4 & 0.617 & Valid & 0.763 & Valid \\
\hline FP2.1 & 0.486 & Not valid & \multicolumn{2}{|c|}{ Dropping done } \\
\hline FP2.2 & 0.623 & Valid & 0.751 & Valid \\
\hline FP2.3 & 0.650 & Valid & 0.836 & Valid \\
\hline FP2.4 & 0.654 & Valid & 0.833 & Valid \\
\hline FP2.5 & 0.501 & Valid & \multicolumn{2}{|c|}{ Dropping done } \\
\hline
\end{tabular}

Nuriza Nenden Irawan; Rindang Matoati. The Influence Of Financial Literacy And Behavior In Using Fintech Payments On The Financial Management Of Jabodetabek Students 


\begin{tabular}{|c|c|c|c|}
\hline FP3.1 & 0.402 & Not valid & Dropping done \\
\hline FP3.2 & 0.330 & Not valid & Dropping done \\
\hline FP3.3 & 0.269 & Not valid & Dropping done \\
\hline FP3.4 & 0.410 & Not valid & Dropping done \\
\hline FP4.1 & 0.542 & Valid & Dropping done \\
\hline FP4.2 & 0.586 & Valid & Dropping done \\
\hline FP4.3 & 0.468 & Not valid & Dropping done \\
\hline FP4.4 & 0.549 & Valid & Dropping done \\
\hline FP5.1 & 0.564 & Valid & Dropping done \\
\hline FP5.2 & 0.682 & Valid & Dropping done \\
\hline FP5.3 & 0.671 & Valid & Dropping done \\
\hline \multicolumn{4}{|c|}{ Financial Management } \\
\hline PK1.1 & 0.470 & Not valid & Dropping done \\
\hline PK1.2 & 0.669 & Valid & Dropping done \\
\hline PK1.3 & 0.666 & Valid & $0.713 \quad$ Valid \\
\hline PK1.4 & 0.580 & Valid & $0.694 \quad$ Valid \\
\hline PK1.5 & 0.618 & Valid & Dropping done \\
\hline PK2.1 & 0.451 & Not valid & Dropping done \\
\hline PK2.2 & 0.611 & Valid & Dropping done \\
\hline PK2.3 & 0.515 & Valid & Dropping done \\
\hline PK2.4 & 0.579 & Valid & Dropping done \\
\hline PK2.5 & 0.606 & Valid & Dropping done \\
\hline PK3.1 & 0.619 & Valid & $0.726 \quad$ Valid \\
\hline PK3.2 & 0.703 & Valid & $0.695 \quad$ Valid \\
\hline PK3.3 & 0.585 & Valid & Dropping done \\
\hline PK4.1 & 0.579 & Valid & $0.730 \quad$ Valid \\
\hline PK4.2 & 0.642 & Valid & 0.746 \\
\hline PK4.3 & 0.663 & Valid & 0.757 \\
\hline PK4.4 & 0.493 & Not valid & Dropping done \\
\hline PK5.1 & 0.439 & Not valid & Dropping done \\
\hline PK5.2 & 0.641 & Valid & \\
\hline PK5.3 & 0.477 & Not valid & $\begin{array}{l}\text { Dropping done } \\
\text { Dropping done }\end{array}$ \\
\hline
\end{tabular}

Sumber: Data diolah (2021)

According to Table 5, there are several indicators that have a loading factor value of less than 0.50 and require that the indicator must be dropped because it will create errors in data processing in SEM-PLS. While the indicators LK1.3, LK1.6, LK2.5, LK3.2, LK4.2, FP2.5, FP4.1, FP4.2, FP4.4, FP5.1, FP5.2, FP5.3 PK1.2, PK1.5, PK2.2, PK2.3, PK2.4, PK2.5, PK3.3, and PK5.2 should also be reduced even though these indicators have a loading factor value of more than 0.50 because will result in an invalid value on the Average Variance Extracted (AVE) test. The results of the final outer model can be seen in Figure 6.

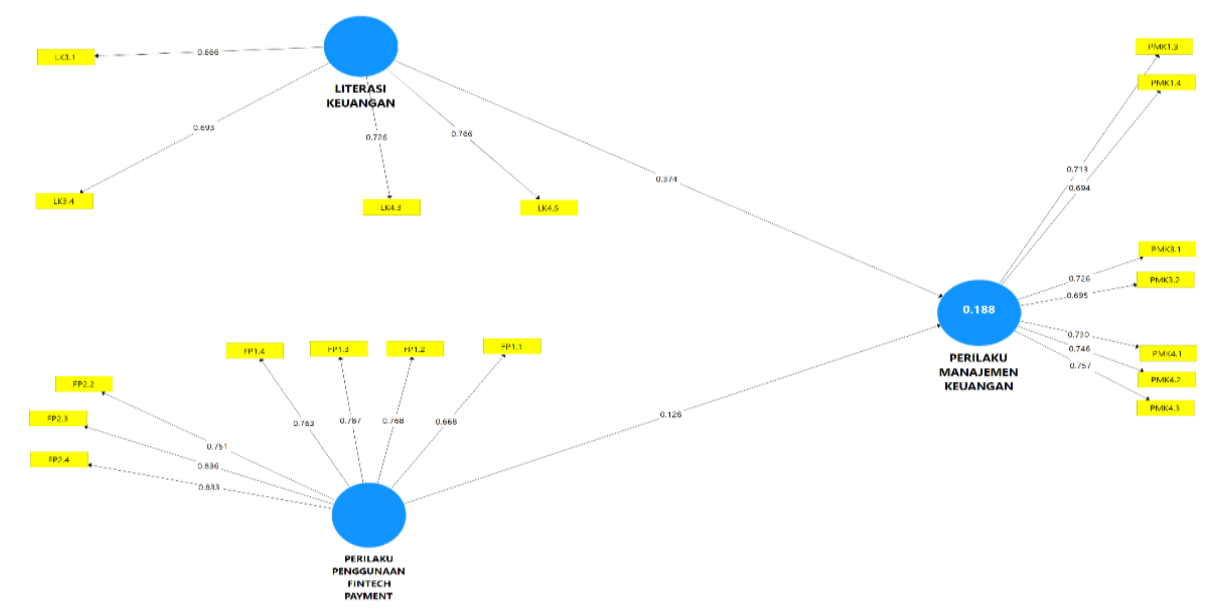

Figure 6 Outer SEM model after dropping Source: Processed data (2021)

Nuriza Nenden Irawan; Rindang Matoati. The Influence Of Financial Literacy And Behavior In Using Fintech Payments On The Financial Management Of Jabodetabek Students 
The next validity test is seen through the Average Variance Extracted (AVE) value. The rule of thumb of the AVE value is that it must be greater than 0.50 . Table 6 shows the AVE value of all latent variables, namely financial literacy, behavior in using fintech payments and financial management for each of the indicators that have been dropped and all of these latent variables have an AVE value of more than 0.50 . It is stated that all latent variables have good convergent validity and the model is constructively valid.

Table 6 Average variance extracted . value

\begin{tabular}{lcc}
\hline \multicolumn{1}{c}{ Latent Variable } & Average Variance Extracted (AVE) & Remarks \\
\hline Financial Literacy & 0.509 & Valid \\
\hline Fintech Payment Behavior & 0.599 & Valid \\
\hline Financial Management & 0.523 & Valid \\
\hline
\end{tabular}

Source: Processed data (2021)

Next, a discriminant validity test was conducted which was assessed According to the value of the cross-loading measurement with its construct. The cross-loading value shows the magnitude of the correlation between each construct and its indicators and indicators from other constructs. The model has good discriminant validity if the correlation between the latent variable and its indicators is higher than the correlation with indicators of other latent variables. The results of cross loading in this research showed that all latent variables had a higher correlation with the indicator compared to other indicators. Therefore, all constructs in this research have met the criteria for discriminant validity.

\section{Reliability Test}

After all variables are declared valid, then the reliability test is conducted by looking at the composite reliability value. The rule of thumb for the composite reliability value in each dimension must be greater than 0.70 . The composite reliability value of all variables has a composite reliability value of more than 0.70 so it can be concluded that the indicators are declared reliable and the indicators have consistency in measuring the latent variables. These are presented in Table 7.

Table 7 Composite reliability values

\begin{tabular}{lcc}
\hline \multicolumn{1}{c}{ Latent Variable } & Composite Reliability Value & Remarks \\
\hline Financial Literacy & 0,805 & Reliable \\
\hline Fintech Payment Behavior & 0.912 & Reliable \\
\hline Financial Management & 0.885 & Reliable \\
\hline
\end{tabular}

Source: Processed data (2021)

\section{Evaluation of the Structural Model (Inner Model)}

The evaluation of the inner model is done by looking at the R-Square value of each endogenous latent variable and looking at the T-statistics value in the estimated path coefficients. The value of R-Square (R2) is used to explain how much influence the exogenous latent variable has on the endogenous latent variable. The value of $R$-Square $(\mathrm{R} 2)$ in this research can be seen in Table 8.

Table 8 Nilai $R$-Square

\begin{tabular}{ccc}
\cline { 2 - 3 } & Latent Variable & $\boldsymbol{R}$-Square $\left.\mathbf{( R}^{2}\right)$ \\
\cline { 2 - 3 } Source: & Prinancial Management & 0.188 \\
\hline
\end{tabular}

Nuriza Nenden Irawan; Rindang Matoati. The Influence Of Financial Literacy And Behavior In Using Fintech Payments On The Financial Management Of Jabodetabek Students 
The value of R-Square (R2) on the financial management variable is 0.188 . This shows that the financial literacy variable and the behavior of using fintech payments are able to explain the financial management variable by $18.80 \%$ and the remaining $81.20 \%$ is explained by other variables outside the model.

Further testing is done by testing the hypothesis to determine the effect between variables through bootstrapping calculations. The results of the bootstrapping evaluation of the structural model can be seen in Figure 7.

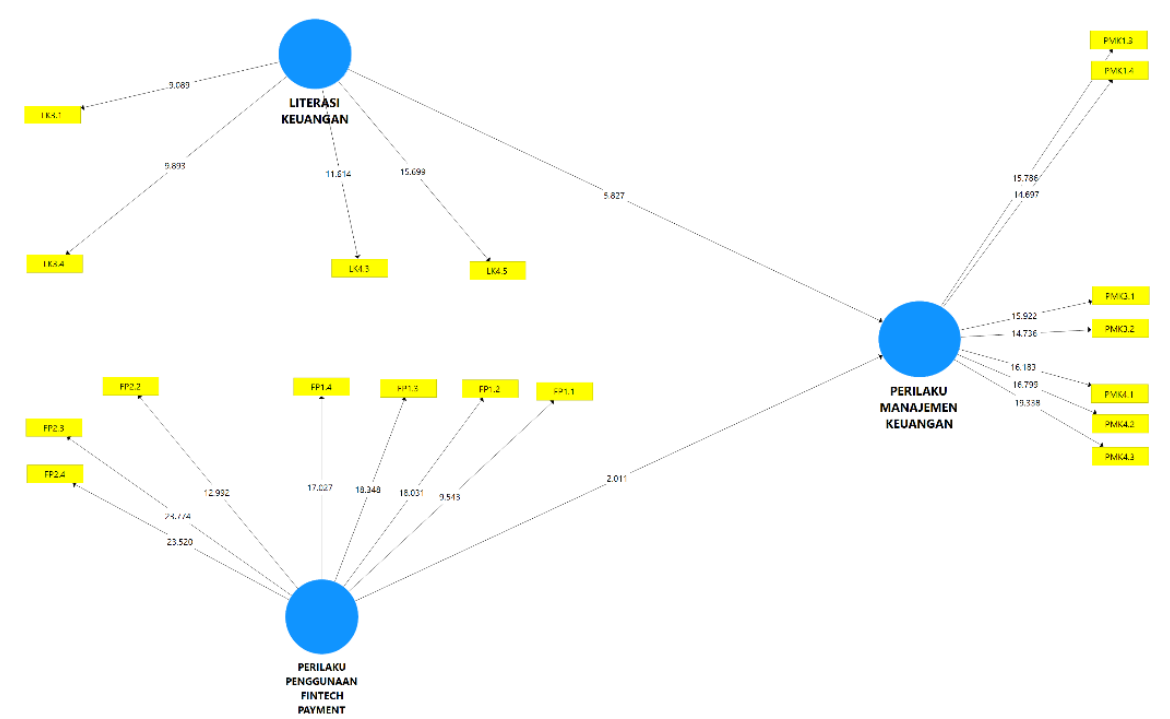

Figure 7 Bootstrapping results on the inner model

Source: Processed data (2021)

The next evaluation of the structural model or inner model is to look at the estimated value of the path coefficient which explains the direct influence of a latent variable with other latent variables. A variable is said to have a relationship and an acceptable hypothesis if the P-values are less than 0.05 and the t-statistics value is greater than the t-table. In this research, the T-table value used for the $95 \%$ confidence level was 1.96. The original sample value is used to determine the direction of the relationship between a variable, either positive or negative in a model.

Table 9 Path coefficient of bootstrapping results

\begin{tabular}{lcccccc}
\hline $\begin{array}{c}\text { Latent Variable } \\
\text { Relationship }\end{array}$ & Hypothesis & $\begin{array}{c}\text { Original } \\
\text { Sample }\end{array}$ & T-Statictics & P-Values & $\begin{array}{c}\text { Hypothesis } \\
\text { Decision }\end{array}$ \\
\hline $\begin{array}{l}\text { Financial Literacy } \\
\text { Financial Management }\end{array}$ & $\rightarrow$ & $\mathrm{H}_{1.1}$ & 0.374 & 5.827 & 0.000 & $\mathrm{H}_{1.1}$ Accepted \\
\hline $\begin{array}{l}\text { Fintech Payment Behavior } \\
\rightarrow \text { Financial Management }\end{array}$ & $\mathrm{H}_{1.2}$ & 0.128 & 2.011 & 0.0445 & $\mathrm{H}_{1.2}$ Accepted \\
\hline
\end{tabular}

Source: Processed data (2021)

According to Table 9, it can be seen from the results of testing the research hypothesis that the results are as follows:

\section{The Influence of Financial Literacy on Financial Mannagement}

Financial literacy has a positive and significant effect on financial management with a t-statistics value of 5.827 and has exceeded the t-table (1.96) and a p-value of 0.000 . The original sample value is positive at 0.374 which indicates that the direction of the relationship between financial literacy and financial management is positive. The hypothesis $\mathrm{H}_{1.1}$ is accepted and $\mathrm{H}_{0.1}$ is rejected, where financial literacy has a significant positive effect on financial management. This shows that students who have a good

Nuriza Nenden Irawan; Rindang Matoati. The Influence Of Financial Literacy And Behavior In Using Fintech Payments On The Financial Management Of Jabodetabek Students 
understanding of financial literacy related to financial planning and expenditure include general knowledge of finance, savings, investment, insurance, and responsibility for finances, they will have better financial management which has an impact on their financial management as well as on the financial decisions taken. Of all the indicators on the financial literacy variable, the indicator of the benefits and risks of investing (LK4.5) from the investment knowledge dimension reflects the financial literacy variable with the largest outer loading value of 0.766 . In these indicators, students already have knowledge about the benefits and risks that come with investing, this is also followed by the LK4.3 indicator which the majority of them understand to reduce risk in investing in stocks, the way that investors can do is to buy various types of shares. This means that students' knowledge of investment can also have an impact on financial management behavior, especially in investing.

The results of this research are in line with the research of Edrisinghe et al. (2017) that student financial literacy has a positive and significant effect on financial behavior, meaning that the higher the knowledge and ability of students in managing finances, the wiser in making financial decisions and being able to convince themselves in solving their financial problems so that the individual tries to manage his finances effectively. either by setting aside some funds to pay bills on time or to save.

\section{The Influence of Fintech Payment Behavior on Financial Management}

The behavior of using fintech payments has a positive and significant effect on financial management with a t-statistics value of 2.011 and has exceeded the t-table (1.96) and a p-value of 0.0445 . The original sample value is positive at 0.128 which indicates that the direction of the relationship between the behavior of using fintech payments and financial management is positive. Thus the hypothesis $\mathrm{H}_{1.2}$ is accepted and $\mathrm{H}_{0.2}$ is rejected, where the behavior of using fintech payments has a significant positive effect on financial management. This shows that the high use of fintech payments among Jabodetabek students is very helpful for students in managing their finances in daily life so that the higher the use and perceived benefits of using fintech payments, both in terms of frequency of use, the number of applications owned, the number of transactions in fintech payments, and the behavioral dimensions of using fintech payments, the financial management of Jabodetabek students will be better and better and can help make decisions in their finances. Of all the indicators on the behavioral variable using fintech payment, the indicator of effectiveness in transactions (FP2.3) from the performance expectancy dimension reflects the behavioral variable using fintech payment, with the largest outer loading value of 0.880 . In this indicator, students think that fintech payments help them effectively in making payment transactions.

The results of this research are in line with the research of Yeo and Fisher (2017) which states that someone with more frequent use of fintech payments, significantly affects the level of good financial management and makes it easier for someone to manage their finances because in one fintech payment application they can make various transactions with such as payment transactions, monitoring expenses and income, to saving.

\section{CONCLUSIONS AND SUGGESTIONS}

\section{Conclusion}

According to the results of the research that has been conducted, several conclusions were obtained which include:

1. The level of financial literacy of Jabodetabek students is divided into two categories, namely $68.50 \%$ of students who are classified as well literate and $31.50 \%$ of students are classified as sufficient literate. The average level of financial literacy of Jabodetabek students is $81.09 \%$ and is classified as well

Nuriza Nenden Irawan; Rindang Matoati. The Influence Of Financial Literacy And Behavior In Using Fintech Payments On The Financial Management Of Jabodetabek Students 
literate which means that Jabodetabek students have knowledge and beliefs about financial service institutions and financial service products, including features, benefits and risks, rights and obligations related to products and services. financial services, as well as having skills in using financial products and services. Meanwhile, the level of behavior in using fintech payments for Jabodetabek students is $84.43 \%$ and is included in the very high category. This shows that fintech payments have grown rapidly among Jabodetabek students and the majority of students have adopted the technology as a transaction medium for their daily needs. And the level of financial management of Jabodetabek students is $80.93 \%$ and is included in the very good category. This shows that the majority of Jabodetabek students are able to manage their finances well and the majority of students always make financial plans and record all their financial income and expenses.

2. Financial literacy has a positive and significant influence on the financial management of Jabodetabek students with a t-statistics value of 5.827 (>1.96), a p-value of 0.000 , and a positive original sample value of 0.3740 .

3. The behavior of using fintech payments has a significant positive effect on financial management with a t-statistics value of 2.011 (> 1.96), a p-value of 0.0445 and a positive original sample value of 0.128 .

\section{Suggestion}

According to the results of the research that has been done, the researchers have several suggestions that can be input which include:

1. For the Financial Services Authority (OJK) and universities, research results can be considered for designing programs to improve financial literacy for students, especially in terms of knowledge about investment and financial product and service instruments.

2. For fintech payment companies to not only increase the ease of access and ease of transactions, but also tighten the security system for fintech payments to avoid fraud and be able to participate in encouraging the creation of a cashless society in Indonesian society.

3. For future researchers, it is recommended to use a sample with a wider area coverage, which is not limited to universities in Jabodetabek, for example, universities throughout Indonesia. In addition, further researchers can also add other variables outside of this research.

\section{REFERENCES}

Asosiasi Penyelenggara Jasa Internet Indonesia. (2020). Laporan Survei Internet APJII 2019-2020 [Q2]. https://apjii.or.id/

Bank Indonesia. (2017). Peraturan Bank Indonesia nomor 19/12/PBI/2017 tentang Penyelenggaraan Teknologi Finansial. https://peraturan.bpk.go.id/Home/Details/135776/peraturan-bi-no-1912pbi2017$\underline{\text { tahun-2017 }}$

Chaulagain, R. P. (2017). Relationship Between Financial Literacy and Behavior of Small Borrowers. NRB Economic Review, 29(3), 33-55.

Chen, V. (1998). An Analysis of Personal Financial Literacy Among College Students. Financial Services Review, 7(2): 107-128. https://doi.org/10.1016/S1057$\underline{0810(99) 80006-7}$

Edirisinghe, et al. (2017). Financial Literacy and Financial Behavior of Management Undergraduates of Sri Lanka. International Journal of Management and Applied Science, 3(7). ISSN: 2394-7926.

Nuriza Nenden Irawan; Rindang Matoati. The Influence Of Financial Literacy And Behavior In Using Fintech Payments On The Financial Management Of Jabodetabek Students 
The Management Journal of BINANIAGA Vol. 06, No.02, December 2021

p-ISSN: 2527 - 4317, e-ISSN: $2580-149 x$

$6^{\text {th }}$ Accreditation Rating: April 04, $2019-$ April 03, 2024

Erlangga, M.Y., Krisnawati, A. (2020). Pengaruh Fintech Payment terhadap Pengelolaan Keuangan Mahasiswa. Jurnal Riset Manajemen dan Bisnis, Vol. 15(1). http://dx.doi.org/10.21460/jrmb.2020.151.348

Fintech Singapore. (2018). Fintech Indonesia Report 2018. https://fintechnews.sg

Ghozali, I. (2014). Structural Equation Modelling, Metode Alternatif dengan Partial Least Square (PLS) (ed. 4). Semarang: Penerbit Universitas Diponegoro.

Hair et al. (2014). Partial least squares structural equation modeling (PLS-SEM): An emerging tool in business research. European business review

Jamil et al. (2016). How Knowledge and Financial Self-Efficacy Moderate the Relationship between Money Attitudes and Personal Financial Management Behavior. European Online Journal of Natural and Social Sciences, 5, 296-308. https://european-science.com/eoinss/article/view/3234

Kim et al. (2016). The adoption of mobile payment services for "Fintech". International Journal of Applied Engineering Research, 11(2), 1058-1061. https://www.semanticscholar.org/paper/The-Adoption-of-Mobile-Payment-Servicesfor-Kim-Choi/2c968789b918883f6f189943f325b44aa69c9b9c

Lemeshow, et al. (1990). Adequacy of Sample Size in Health Studies. Chichester:Wiley.

Margaretha, F., Pambudhi, R.A. (2015). Tingkat Literasi Keuangan Pada Mahasiswa S-1. Jurnal Manajemen dan Kewirausahaan, 17(1), 76-85. https://doi.org/10.9744/jmk.17.1.76

Otoritas Jasa Keuangan. (2013). Literasi Keuangan. http://www.ojk.go.id

Otoritas Jasa Keuangan. (2016). Peraturan Presiden Nomor 82 Tahun 2016 Tentang Strategi Nasional Keuangan Inklusif. http://www.ojk.go.id

Otoritas Jasa Keuangan. (2017). Strategi Nasional Literasi Keuangan Indonesia (Revisit 2017). http://www.ojk.go.id

Otoritas Jasa Keuangan. (2020). Survei Nasional Literasi dan Inklusi Keuangan 2019. http://www.ojk.go.id

See-To, E. W. K., Ngai, E. W. T. (2019). An empirical study of payment technologies, the psychology of consumption, and spending behavior in a retailing context. Information and Management, 56(3), 329-342. https://doi.org/10.1016/j.im.2018.07.007

Statista. (2020). Fintech Report 2021. https://www.statista.com/

Sugiyono. (2016). Metode Penelitian Kuantitatif, Kualitatif dan R\&D. Bandung: Alfabeta

Xiao, J.J., Dew, J. (2011). The financial management behavior scale: Development and validation. Journal of Financial Counseling and Planning. 22(1):43-59. https://www.researchgate.net/publication/256019544 The Financial Management Behavior Scale Development and Validation

Yeo, J.H., Fisher, P. J., (2017). Mobile Financial Technology and Consumers' Financial Capability in the United States. Journal Of Education \& Social Policy, 7(1), 80-93. http://www.jespnet.com/journals/Vol 4 No 1 March 2017/11.pdf

Nuriza Nenden Irawan; Rindang Matoati. The Influence Of Financial Literacy And Behavior In Using Fintech Payments On The Financial Management Of Jabodetabek Students 
The Management Journal of BINANIAGA Vol. 06, No.02, December 2021

p-ISSN: $2527-4317$, e-ISSN: $2580-149 x$

$6^{\text {th }}$ Accreditation Rating: April 04, 2019- April 03, 2024

Nuriza Nenden Irawan; Rindang Matoati. The Influence Of Financial Literacy And Behavior In Using Fintech Payments On The Financial Management Of Jabodetabek Students 